\title{
Report
}

\section{Distribution and Causes of Global Forest Fragmentation}

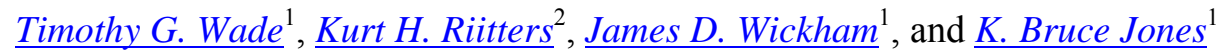

\begin{abstract}
Because human land uses tend to expand over time, forests that share a high proportion of their borders with anthropogenic uses are at higher risk of further degradation than forests that share a high proportion of their borders with non-forest, natural land cover (e.g., wetland). Using 1-km advanced very high resolution radiometer (AVHRR) satellite-based land cover, we present a method to separate forest fragmentation into natural and anthropogenic components, and report results for all inhabited continents summarized by World Wildlife Fund biomes. Globally, over half of the temperate broadleaf and mixed forest biome and nearly one quarter of the tropical rainforest biome have been fragmented or removed by humans, as opposed to only $4 \%$ of the boreal forest. Overall, Europe had the most human-caused fragmentation and South America the least. This method may allow for improved risk assessments and better targeting for protection and remediation by identifying areas with high amounts of human-caused fragmentation.
\end{abstract}

\section{INTRODUCTION}

Global deforestation has been documented extensively, with an emphasis on the loss of tropical rainforests in Central Africa and Amazonia and the impacts on global climate and carbon budgets (Fearnside 1996, Laurance 2000, Justice et al. 2001, Semazzi and Yi 2001, Zhang et al. 2001). Another consequence is change in forest dynamics from fragmentation. Alteration of forest spatial patterns affects wildlife habitat quality and biodiversity in both tropical forests (Gascon and Lovejoy 1998, Carvalho and Vasconcelos 1999, Scariot 1999, Laurance et al. 2000) and extra-tropical forests (Jules et al. 1999, Hargis et al. 1999, Kurki et al. 2000, Virgos 2001).

Forest area statistics are available from several sources. The United Nations Food and Agriculture Organization (FAO) produces the Forest Resources Assessment every 10 years, which estimates global forest area and change over time (Holmgren 2001), and the World Resources Institute (WRI) has published the Pilot Analysis of Global Ecosystems, which includes a forest ecosystems component (Matthews et al. 2000). Estimates for some areas are based on incomplete or inconsistent data, and methodological differences make comparisons difficult (Matthews 2001). Nevertheless, in the preceding decade we have witnessed a continuing reduction in global forest area with apparently substantial reductions occurring mainly in tropical areas.
There has not been a systematic analysis of human vs. natural sources of forest fragmentation at the global scale. Frontier forests, defined as "large, ecologically intact, and relatively undisturbed natural forest," have been mapped globally and a qualitative threat rating has been assigned to each patch (Bryant et al. 1997). Pahari and Murai (1999) demonstrated the high correlation between human population density and cumulative forest loss for regions. Matthews et al. (2000) recognized fragmentation as an issue separate from forest loss, and discussed deforestation and fragmentation caused by humans on a global scale. Riitters et al. (2000) quantified total forest fragmentation across multiple evaluation scales but did not identify human-caused fragmentation. Jones et al. (1999) assessed forest patch vulnerability based on edge shared with anthropogenic and natural land uses but only examined three tropical areas. A systematic global assessment is needed because anthropogenic land uses tend to expand or change over time and, as a result, areas that now experience humaninduced fragmentation are more likely to be areas of changing forest patterns in the future. This is especially true in tropical regions experiencing direct forest loss, but also applies to shifts in land uses in regions where total forest area is more or less constant, such as in North America.

Forests may be fragmented by a number of activities or events, such as road construction, logging, conversion to agriculture, or wildfire, but ultimately, the fragmenting cause is either anthropogenic or natural in origin. In this paper, we present a method to 
calculate the amount of human and naturally caused forest fragmentation on a global scale using 1-km land cover data. The method quantifies fragmentation based on edges between forest and neighboring pixels, and identifies the cause as either anthropogenic or natural. We report the amount of anthropogenic and natural forest fragmentation for six continents by World Wildlife Fund (WWF) biomes (Olson et al. 2001). Because of interest in tropical forest ecosystems, we also report the results by WWF ecoregions for the tropical and subtropical moist broadleaf forest biome (TrMB hereafter) in South America.

Table 1. Original IGBP and re-classification used in the fragmentation analysis.

IGBP Classification

1 Evergreen Needleleaf Forest

2 Evergreen Broadleaf Forest

3 Deciduous Needleleaf Forest

4 Deciduous Broadleaf Forest

5 Mixed Forest

6 Closed Shrublands

7 Open Shrublands

8 Woody Savannas

9 Savannas

10 Grasslands

11 Permanent Wetlands

12 Croplands

13 Urban and Built-Up

14 Cropland/Natural Vegetation Mosaic

15 Snow and Ice

16 Barren or Sparsely Vegetated

17 Water Bodies
Reclassified to

Forest

Forest

Forest

Forest

Forest

Other Natural

Other Natural

Forest

Other Natural

Other Natural

Other Natural

Anthropogenic

Anthropogenic

Anthropogenic

Ignored

Other Natural

Ignored

\section{METHODS}

We used land cover maps from the Global Land Cover Characteristics (GLCC) database (version 2.0). The maps were derived from advanced very high resolution radiometer (AVHRR) satellite imagery acquired between April 1992 and March 1993 and have a spatial resolution of $1 \mathrm{~km}$ (Loveland et al. 2000). The GLCC distributes maps of Eurasia as a single entity; we separated this into Europe (including the Arabian Peninsula) and Asia along an axis tracing the Ural Mountain Range. We used the 17-class International Geosphere Biosphere Programme (IGBP) map legend (Loveland and Belward 1997) and re-classified each pixel as anthropogenic, forest, or other natural land cover types (Table 1). Snow, ice, and water bodies were treated as missing data and were not permitted to fragment the forest land cover in the analysis.

For data summaries, we used selected WWF biomes (Olson et al. 2001) to stratify the continental analyses of fragmentation (Fig. 1A-F). Eight forest and woodland biomes were considered; forest land in other biome types was not included in our analysis. To facilitate later comparisons, we also calculated the percentage of each global biome found on each continent (Table 2) and the percentage of the global biome area that was in each of the three land cover types on each continent (Table 3). 
Fig. 1. World Wildlife Fund biomes. After Olsen et al. (2001). To view a larger version of this figure, go to http://www.consecol.org/vol7/iss2/art7/figure1.html.
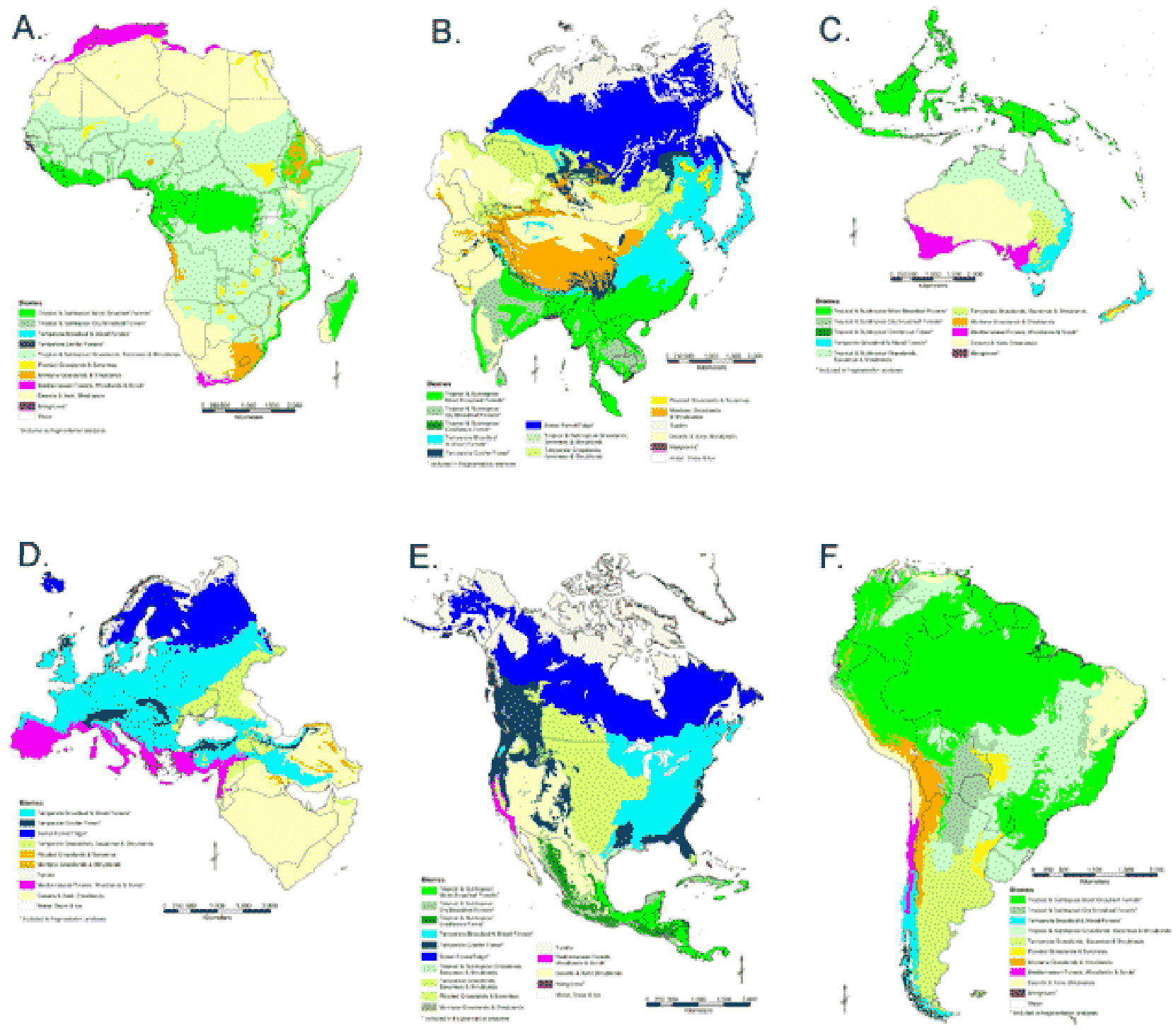

To perform the fragmentation calculations, we used a "moving window" algorithm (e.g., Riitters et al. 2000) with a single window size of $9 \times 9$ pixels (i.e., 8100 ha). The window was centered on each land cover pixel (forested or not), a fragmentation score was calculated for the window, and the result was assigned to the center pixel. Maps of four indices were produced for each continent to characterize forest fragmentation by anthropogenic pixels $\left(\mathrm{P}_{\mathrm{fa}}\right)$, forest fragmentation by non-forest natural land cover pixels $\left(\mathrm{P}_{\mathrm{fn}}\right)$, overall forest connectivity $\left(\mathrm{P}_{\mathrm{ff}}\right)$, and forest area density $\left(\mathrm{P}_{\mathrm{f}}\right)$. The computations are illustrated in Fig. 2. Using the same algorithm as Riitters et al. (2000), $\mathrm{P}_{\mathrm{f}}$ was the proportion of the window that was forest, and $P_{\mathrm{ff}}$ was the ratio of the number of adjacent (cardinal directions only) pixel pairs for which both pixels were forest to the number of adjacent pixel pairs where either one or both pixels was forest. 
Table 2. Percentage of biome area contained on each continent and percentage of global land surface area occupied by each biome.

\begin{tabular}{|c|c|c|c|c|c|c|c|}
\hline Biome & Africa & Asia & Australia & Europe & $\begin{array}{l}\mathrm{N} . \\
\text { America }\end{array}$ & $\begin{array}{l}\text { S. } \\
\text { America }\end{array}$ & Global \\
\hline $\begin{array}{l}\text { Tropical \& } \\
\text { Subtropical Moist } \\
\text { Broadleaf Forest }\end{array}$ & 17.66 & 21.89 & 13.79 & 0.00 & 3.16 & 43.50 & 14.98 \\
\hline $\begin{array}{l}\text { Tropical \& } \\
\text { Subtropical Dry } \\
\text { Broadleaf Forest }\end{array}$ & 5.26 & 42.40 & 2.37 & 0.00 & 14.44 & 35.54 & 2.74 \\
\hline $\begin{array}{l}\text { Tropical \& } \\
\text { Subtropical } \\
\text { Coniferous Forest }\end{array}$ & 0.00 & 12.35 & 1.41 & 0.00 & 86.24 & 0.00 & 0.53 \\
\hline $\begin{array}{l}\text { Temperate Broadleaf } \\
\text { \& Mixed Forest }\end{array}$ & 0.01 & 27.66 & 5.73 & 41.41 & 22.25 & 2.95 & 9.69 \\
\hline $\begin{array}{l}\text { Temperate Conifer } \\
\text { For. }\end{array}$ & 0.57 & 31.39 & 0.00 & 11.72 & 56.32 & 0.00 & 3.09 \\
\hline Boreal Forests/Taiga & 0.00 & 50.44 & 0.00 & 15.73 & 33.83 & 0.00 & 11.43 \\
\hline Mediterranean & 26.54 & 0.00 & 25.07 & 40.02 & 3.75 & 4.63 & 2.43 \\
\hline Mangroves & 23.16 & 24.18 & 18.16 & 0.00 & 17.03 & 17.47 & 0.23 \\
\hline
\end{tabular}

A new method was developed to partition total forest fragmentation into components that correspond to $\mathrm{P}_{\mathrm{fn}}$ and $\mathrm{P}_{\mathrm{fa}}$ sources. First, we defined total fragmentation $\left(F_{t}\right)$ as the sum of natural and anthropogenic fragmentation, and the complement of overall forest connectivity:

$F_{t}=\left(P_{f n}+P_{f a}\right)=\left(1-P_{f f}\right)$

To compute the natural component of total forest fragmentation $\left(\mathrm{P}_{\mathrm{fn}}\right)$, we used the same denominator as for $\mathrm{P}_{\mathrm{ff}}$, and calculated the proportion of adjacent pixel pairs involving forest for which one pixel was forest and the other was a non-forest, natural land cover type. Similarly, fragmentation due to humans $\left(\mathrm{P}_{\mathrm{fa}}\right)$ was the proportion of adjacent pixel pairs involving forest for which one pixel was forest and the other was an anthropogenic land use type. All of the indices range from 0 to 1 and were rescaled to a range of 0 to 100 for data summaries.

Some forest biomes contain relatively little forest and, as a result, indices based on the present forest will underestimate fragmentation owing to deforestation. The following procedure was used in an attempt to capture that aspect of fragmentation. Windows containing no forest, whose center cell had an anthropogenic land use, were assigned $\mathrm{P}_{\mathrm{fa}}$ values of 100 (and $\mathrm{P}_{\mathrm{fn}}$ and $\mathrm{P}_{\mathrm{ff}}$ were set to zero). The rationale is that, because only forest biomes were considered, any location that was developed and whose surrounding 9 $\times 9$ neighborhood contained no forest, was more likely to have been deforested than to have never supported forest at all. Our rationale is supported by the observation that globally, $70 \%$ of the windows that met the conditions were $>95 \%$ developed. Note that $P_{f a}$ also equals 100 if a window contains only isolated forest pixels that are only adjacent to developed pixels, and our procedures do not distinguish between the two cases. The procedure may overestimate anthropogenic fragmentation in biomes with large proportions of nonforest natural land cover (e.g., temperate coniferous in Asia and Europe, boreal in North America, and Mediterranean on all continents; see Table 2). 
Conversely, when land cover was non-forest natural and the associated neighborhood contained no forest, the cell was ignored in analyses. This case assumes that the area was a non-forested patch within the forest biome that never supported forest. Under these assumptions, $\mathrm{P}_{\mathrm{fa}}$ reflects both the amount of forest and its fragmentation relative to undisturbed conditions.

Table 3. Percent of re-classified land cover by World Wildlife Fund biome and continent. Bold indicates biomes that occupy more than $10 \%$ of the continent land area. For example, $7.7 \%$ of the land area in Africa is re-classified forest in the Tropical and Subtropical Moist Broadleaf Forest biome. Columns do not sum to 100 because only forest biomes are included.

\begin{tabular}{|c|c|c|c|c|c|c|c|c|c|c|c|c|c|c|c|c|c|c|}
\hline \multirow[b]{2}{*}{ Biome } & \multicolumn{3}{|c|}{ Africa } & \multicolumn{3}{|c|}{ Asia } & \multicolumn{3}{|c|}{ Australia } & \multicolumn{3}{|c|}{ Europe } & \multicolumn{3}{|c|}{ N. America } & \multicolumn{3}{|c|}{ S. America } \\
\hline & $\mathrm{F}$ & $\mathrm{N}$ & A & $\mathrm{F}$ & $\mathrm{N}$ & A & $\mathrm{F}$ & $\mathrm{N}$ & A & $\mathrm{F}$ & $\mathrm{N}$ & A & $\mathrm{F}$ & $\mathrm{N}$ & A & $\mathrm{F}$ & $\mathrm{N}$ & A \\
\hline $\begin{array}{l}\text { Tropical \& Subtropical } \\
\text { Moist Broadleaf Forest }\end{array}$ & 7.7 & 1.7 & 2.2 & 8.2 & 1.0 & 9.9 & 15.1 & 2.1 & 7.7 & 0 & 0 & 0 & 1.8 & 0.2 & 1.0 & 38.4 & 3.4 & 6.4 \\
\hline $\begin{array}{l}\text { Tropical \& Subtropical } \\
\text { Dry Broadleaf Forest }\end{array}$ & 0.1 & 0.4 & 0.1 & 1.2 & 0.1 & 5.4 & 0.4 & $<0.1$ & 0.4 & 0 & 0 & 0 & 1.5 & 0.2 & 0.9 & 4.1 & 1.5 & 1.8 \\
\hline $\begin{array}{l}\text { Tropical \& Subtropical } \\
\text { Coniferous Forest }\end{array}$ & 0 & 0 & 0 & 0.1 & 0.1 & 0.2 & $<0.1$ & $<0.1$ & 0.1 & 0 & 0 & 0 & 2.0 & 0.3 & 0.6 & 0 & 0 & 0 \\
\hline $\begin{array}{l}\text { Temperate Broadleaf \& } \\
\text { Mixed Forest }\end{array}$ & $<0.1$ & $<0.1$ & $<0.1$ & 4.1 & 1.8 & 7.2 & 4.0 & 1.4 & 1.3 & 6.1 & 3.1 & 24.5 & 8.5 & $<0.1$ & 4.9 & 1.3 & 0.5 & 0.1 \\
\hline Temperate Conifer For. & $<0.1$ & $<0.1$ & $<0.1$ & 1.3 & 2.0 & 0.5 & 0 & 0 & 0 & 1.1 & 0.7 & 1.2 & 8.2 & 1.3 & 1.4 & 0 & 0 & 0 \\
\hline Boreal Forests/Taiga & 0 & 0 & 0 & 0.4 & 0.1 & $<0.1$ & 0 & 0 & 0 & 11.7 & 0.8 & 1.9 & 12.8 & 10.2 & 0.2 & 0 & 0 & 0 \\
\hline Mediterranean & 0.2 & 2.4 & 0.3 & 0 & 0 & 0 & 1.4 & 3.4 & 2.7 & 1.2 & 1.6 & 5.4 & 0.3 & 0.2 & $<0.1$ & 0.1 & 0.5 & 0.2 \\
\hline Mangroves & 0.1 & 0.1 & 0.1 & $<0.1$ & 0.1 & 0.2 & 0.3 & $<0.1$ & 0.1 & 0 & 0 & 0 & 0.1 & $<0.1$ & 0.1 & 0.2 & $<0.1$ & 0.1 \\
\hline
\end{tabular}

Several tabular and graphical summaries were generated to assist in the interpretations of the relationships between $\mathrm{P}_{\mathrm{ff}}, \mathrm{P}_{\mathrm{fa}}, \mathrm{P}_{\mathrm{fn}}$, and $\mathrm{P}_{\mathrm{f}}$. Tabular summaries were prepared for eight forest biomes and six continents, but only 36 of the possible 48 combinations were realized because some biomes did not occur on some continents. The forest connectivity index $\left(\mathrm{P}_{\mathrm{ff}}\right)$ was also summarized based on threshold values of $60 \%$ ("connected") and $100 \%$ ("interior"), where the $60 \%$ threshold was chosen by analogy to percolation theory (Stauffer 1985), assuming a random distribution of forest in a window (Gardner et al. 1987). Tables were prepared to show average $P_{f a}$ and $\mathrm{P}_{\mathrm{fn}}$ values by percentage for forest WWF biomes by continent and, for the one biome in South America, by using WWF ecoregions within that biome. A scatter plot of average biome $\mathrm{P}_{\mathrm{f}}$ and $\mathrm{P}_{\mathrm{fa}}$ by continent was also produced to allow graphical interpretation of the data

After Milne (1992), color composites of $\mathrm{P}_{\mathrm{ff}}$ (green), $\mathrm{P}_{\mathrm{fa}}$ (red), and $\mathrm{P}_{\mathrm{fn}}$ (blue) were constructed to provide spatial views of the changing dominance of the individual metrics in different places. To saturate color and improve legibility, the highest value among $\mathrm{P}_{\mathrm{ff}}, \mathrm{P}_{\mathrm{fa}}$ and $\mathrm{P}_{\mathrm{fn}}$ was multiplied by a scaling factor so that it equaled 255. Each of the other two values was also multiplied by the same factor. The color composite maps show highly connected forest in green, and forest with large amounts of natural fragmentation in blue. Deforested areas and forest that was highly fragmented by human use are shown in red. Areas where $\mathrm{P}_{\mathrm{ff}}$ and $\mathrm{P}_{\mathrm{fa}}$ were approximately equal are rendered in yellow and areas where $\mathrm{P}_{\mathrm{ff}}$ and $\mathrm{P}_{\mathrm{fn}}$ were approximately equal are displayed in cyan. Pixels that were a non-forest 
natural class and had no forest in their $9 \times 9$ window were displayed in black, and missing values (including non-forest biomes) were shown in white.

The color composite maps were complemented by maps illustrating the standard deviation of $\mathrm{P}_{\mathrm{fa}}$. Although the composite maps display absolute amounts of $\mathrm{P}_{\mathrm{ff}}, \mathrm{P}_{\mathrm{fa}}$ and $\mathrm{P}_{\mathrm{fn}}$, standard deviation maps show the level of $\mathrm{P}_{\mathrm{fa}}$ relative to the rest of the biome by continent. These maps were constructed by first calculating the mean and standard deviation $\mathrm{P}_{\mathrm{fa}}$ value for each continent and biome. Any pixel with a $\mathrm{P}_{\mathrm{fa}}$ value more than two standard deviations above the mean was then displayed in red, pixels between one and two standard deviations above the mean were pink, and pixels within one standard deviation of the mean were white. Pixels between one and two standard deviations below the mean were shown in light green, and pixels more than two standard deviations below the mean were dark green. In many biomes, the standard deviation was greater than the mean and, as a result, it was impossible to have any green areas in the biome. To compensate for that artifact, the areas with no fragmentation $\left(\mathrm{P}_{\mathrm{fa}}\right.$ values of zero) were always displayed in dark green.

Fig. 2. Example showing the calculation of $P_{f a}, P_{f n}$, and $P_{f f}$ in a $3 \times 3$ pixel analysis window containing three types of land cover. An "edge" is the imaginary line that separates any two adjacent pixels. The analysis presented used $9 \times 9$ pixel analysis windows. See text for additional explanation.

\begin{tabular}{|l|l|l|}
\hline$A$ & A & N \\
\hline N & F & F \\
\hline N & F & F \\
\hline
\end{tabular}

$A=$ Anthropogenic land-use, $N=$ Non-forest natural landcover and $\mathrm{F}=$ Forest.

Total F-A edges $=1$

Total F-N edges $=3$

Total F-F edges $=4$

Total F-any edges $=8$

\section{RESULTS}

The continental proportion of forest in a biome that is "connected" (i.e., $\mathrm{P}_{\mathrm{ff}}>=60 \%$ ) is a general indicator of the degree of fragmentation, and the proportion that is "interior" $\left(\mathrm{P}_{\mathrm{ff}}=100 \%\right)$ indicates how much forest is relatively remote from other land cover types. At least half the biome area was "connected" forest in 18 of the 36 combinations of biome and continent (Table 4), and 11 of the 18 cases were in North and South America. Only one of six biomes in Africa, and one of four in Europe were more than half "connected" forest. In all these cases, forest tends to be the dominant land cover type in the locations where forest is found. Relatively high proportions of "interior" forest were found in the TrMB biome in Africa and South America, and in all boreal biomes.
Table 5 shows the partitioning of fragmentation into anthropogenic and natural components. Globally, with the exception of the boreal and temperate conifer forest biomes, human-caused fragmentation was typically at least three times more prevalent than natural fragmentation. Out of 36 combinations of biome and continent, anthropogenic fragmentation was greater than natural fragmentation in 27 cases. In the TrMB and temperate broadleaf and mixed forest biomes, which together account for over half of all forest cover, $\mathrm{P}_{\mathrm{fa}}$ was substantially higher than $\mathrm{P}_{\mathrm{fn}}$. Europe was particularly impacted by human fragmentation in all forest biomes. Even in the boreal forest biome, which globally had low fragmentation and little human influence, $\mathrm{P}_{\mathrm{fa}}$ was almost three times greater than $\mathrm{P}_{\mathrm{fn}}$, indicating that most fragmentation was anthropogenic in origin. This is not entirely 
unexpected, as we only used forest biomes where conversion was more likely to be a result of human activity than natural forces, increasing $\mathrm{P}_{\mathrm{fa}}$ relative to $\mathrm{P}_{\mathrm{fn}}$. Of the nine cases where natural fragmentation was greater than human fragmentation, eight occurred in biomes that occupied less than $2 \%$ of the continental area (e.g., mangroves) or that could be considered as "naturally patchy" biome types (e.g., Mediterranean or boreal). Africa was affected more by natural fragmentation in four of six biomes, but the area contained in three of these biomes was very small.

Table 4. Percentage of connected $\left(C ; P_{\mathrm{ff}}>=60 \%\right)$ and interior ( $\left.\mathrm{I} ; \mathrm{P}_{\mathrm{ff}}=100 \%\right)$ forest pixels by continent and biome. For any combination of continent and biome, the sum of percentages may exceed $100 \%$ because connected forest includes interior forest by definition, and the sum may be less than $100 \%$ as not all forest is connected or interior.

\begin{tabular}{|c|c|c|c|c|c|c|c|c|c|c|c|c|}
\hline \multirow[b]{2}{*}{ Biome } & \multicolumn{2}{|c|}{ Africa } & \multicolumn{2}{|c|}{ Asia } & \multicolumn{2}{|c|}{ Australia } & \multicolumn{2}{|c|}{ Europe } & \multicolumn{2}{|c|}{ N. America } & \multicolumn{2}{|c|}{ S. America } \\
\hline & $\mathrm{C}$ & I & $\mathrm{C}$ & I & $\mathrm{C}$ & I & $\mathrm{C}$ & I & $\mathrm{C}$ & I & $\mathrm{C}$ & I \\
\hline $\begin{array}{l}\text { Tropical \& } \\
\text { Subtropical Moist } \\
\text { Broadleaf Forest }\end{array}$ & 69.58 & 38.15 & 43.64 & 16.11 & 61.27 & 20.99 & NA & NA & 59.57 & 12.65 & 81.56 & 49.12 \\
\hline $\begin{array}{l}\text { Tropical \& } \\
\text { Subtropical Dry } \\
\text { Broadleaf Forest }\end{array}$ & 28.15 & 2.01 & 18.58 & 2.47 & 46.89 & 3.77 & NA & NA & 60.26 & 19.83 & 60.02 & 23.70 \\
\hline $\begin{array}{l}\text { Tropical \& } \\
\text { Subtropical } \\
\text { Coniferous Forest }\end{array}$ & NA & NA & 30.83 & 7.11 & 25.49 & 13.02 & NA & NA & 73.48 & 23.03 & NA & NA \\
\hline $\begin{array}{l}\text { Temperate } \\
\text { Broadleaf \& } \\
\text { Mixed Forest }\end{array}$ & 35.65 & 0.00 & 38.08 & 12.32 & 65.29 & 27.53 & 17.02 & 2.02 & 64.77 & 27.06 & 74.98 & 26.79 \\
\hline $\begin{array}{l}\text { Temperate } \\
\text { Conifer For. }\end{array}$ & 40.34 & 1.31 & 57.84 & 24.79 & NA & NA & 37.45 & 2.09 & 80.03 & 32.87 & NA & NA \\
\hline $\begin{array}{l}\text { Boreal } \\
\text { Forests/Taiga }\end{array}$ & NA & NA & 85.95 & 48.52 & NA & NA & 83.03 & 43.26 & 74.75 & 41.77 & NA & NA \\
\hline Mediterranean & 16.66 & 0.37 & NA & NA & 26.83 & 3.30 & 13.99 & 0.38 & 65.75 & 18.03 & 18.00 & 7.70 \\
\hline Mangroves & 31.94 & 1.08 & 17.38 & 0.57 & 70.40 & 30.38 & NA & NA & 32.77 & 2.20 & 56.10 & 9.83 \\
\hline
\end{tabular}

It is helpful to evaluate human-caused fragmentation by taking into account the amount of forest that is represented (Fig. 3). Biomes with a high (or low) proportion of forest are necessarily less (or more) fragmented according to our model. However, for a given amount of forest, there can be more or less human-caused fragmentation depending on the biome, and the differences among biomes may indicate opportunities for restoration or preservation. Except for boreal forests, European forests were in the poorest condition, with very low $\mathrm{P}_{\mathrm{f}}$ and very high $\mathrm{P}_{\mathrm{fa}}$. South
American forests were in the best condition, with high $\mathrm{P}_{\mathrm{f}}$ and low $\mathrm{P}_{\mathrm{fa}}$ relative to the other continents, especially in the TrMB biome, which contained most of the forest on the continent. Because of the high level of current interest in tropical forest condition in general and Amazonia in particular, fragmentation was further stratified by ecoregion for the TrMB biome in South America. Average $\mathrm{P}_{\mathrm{fa}}$ and $\mathrm{P}_{\mathrm{fn}}$ for the biome were 13.43 and 4.21 , respectively, but the 54 component ecoregions ranged from 2.02 to 86.75 for $\mathrm{P}_{\mathrm{fa}}$ and 0.05 to 36.30 for $\mathrm{P}_{\mathrm{fn}}$ (Table 6). 
Table 5. Average percent $P_{f a}$ and $P_{f n}$ by World Wildlife Fund biome and continent. Higher values indicate more fragmentation, and the ratio of $\mathrm{P}_{\mathrm{fa}}$ to $\mathrm{P}_{\mathrm{fn}}$ indicates the relative importance of human-caused fragmentation compared with natural fragmentation.

\begin{tabular}{|c|c|c|c|c|c|c|c|c|c|c|c|c|c|c|}
\hline \multirow[b]{2}{*}{ Biome } & \multicolumn{2}{|c|}{ Africa } & \multicolumn{2}{|c|}{ Asia } & \multicolumn{2}{|c|}{ Australia } & \multicolumn{2}{|c|}{ Europe } & \multicolumn{2}{|c|}{ N. America } & \multicolumn{2}{|c|}{ S. America } & \multicolumn{2}{|c|}{ Global } \\
\hline & Pfa & Pfn & Pfa & Pfn & Pfa & Pfn & Pfa & Pfn & Pfa & Pfn & Pfa & Pfn & Pfa & Pfn \\
\hline $\begin{array}{l}\text { Tropical \& } \\
\text { Subtropical Moist } \\
\text { Broadleaf Forest }\end{array}$ & 18.33 & 8.63 & 48.40 & 3.69 & 29.85 & 6.34 & NA & NA & 30.82 & 6.40 & 13.43 & 4.21 & 24.87 & 5.22 \\
\hline $\begin{array}{l}\text { Tropical \& } \\
\text { Subtropical Dry } \\
\text { Broadleaf Forest }\end{array}$ & 24.21 & 35.69 & 75.72 & 0.98 & 44.35 & 1.59 & NA & NA & 31.14 & 5.11 & 24.74 & 11.35 & 48.80 & 6.48 \\
\hline $\begin{array}{l}\text { Tropical \& } \\
\text { Subtropical } \\
\text { Coniferous Forest }\end{array}$ & NA & NA & 44.53 & 13.68 & 66.77 & 0.25 & NA & NA & 17.93 & 8.41 & NA & NA & 21.71 & 8.90 \\
\hline $\begin{array}{l}\text { Temperate } \\
\text { Broadleaf \& } \\
\text { Mixed Forest }\end{array}$ & 19.42 & 24.59 & 49.91 & 8.51 & 17.80 & 14.97 & 73.67 & 1.46 & 33.74 & 0.23 & 7.01 & 17.96 & 52.78 & 4.36 \\
\hline $\begin{array}{l}\text { Temperate } \\
\text { Conifer For. }\end{array}$ & 30.82 & 20.50 & 13.33 & 24.01 & NA & NA & 45.05 & 9.64 & 11.61 & 9.37 & NA & NA & 15.88 & 13.64 \\
\hline $\begin{array}{l}\text { Boreal } \\
\text { Forests/Taiga }\end{array}$ & NA & NA & 2.97 & 11.54 & NA & NA & 12.90 & 4.36 & 1.25 & 21.65 & NA & NA & 4.18 & 13.09 \\
\hline Mediterranean & 35.45 & 36.03 & NA & NA & 45.62 & 22.10 & 68.83 & 9.59 & 6.34 & 26.70 & 65.96 & 8.31 & 55.38 & 16.94 \\
\hline Mangroves & 26.24 & 29.42 & 73.95 & 4.15 & 22.42 & 4.79 & NA & NA & 41.10 & 13.65 & 30.01 & 7.88 & 39.30 & 12.51 \\
\hline
\end{tabular}

Color composite maps (Fig. 4A-F) show specific areas representing human-caused (red) and natural (blue) forest fragmentation and well-connected forest (green). Yellow delineates transitions between areas of high connectivity and high human fragmentation and cyan identifies ecotones. As only forest biomes were included, ecotones were somewhat uncommon on the maps. The maps clearly showed the areas dominated by anthropogenic fragmentation and generally low amount of $\mathrm{P}_{\text {fn }}$ globally. In particular, the non-boreal forest biomes in Asia (Fig. 4B) and Europe (Fig. 4D) showed widespread human fragmentation. The TrMB biome in Africa (Fig. 4A) and South America (Fig. 4F) were largely intact except in coastal regions. Natural fragmentation was found most commonly in Asia (Fig. 4B) and North America (Fig. $4 \mathrm{E})$ where boreal forest gave way to tundra.
Standard deviation maps (Fig. 5A-F) compared $\mathrm{P}_{\mathrm{fa}}$ values within biomes for each continent. Patterns in these maps had much in common with the color composites, as areas of high absolute $\mathrm{P}_{\mathrm{fa}}$ also had generally high $\mathrm{P}_{\mathrm{fa}}$ relative to the rest of the biome. Perhaps most interesting was Europe (Fig. 5D), which had extremely high $\mathrm{P}_{\mathrm{fa}}$ values relative to other continents and was mostly red in Fig. 4D. By using relative $\mathrm{P}_{\mathrm{fa}}$ values within Europe, forests appeared to be in good condition (Fig. 5D) with patches of below average $\mathrm{P}_{\mathrm{fa}}$ (light green) scattered throughout the continent. The only red area was the southern edge of the boreal forest, with the largest patch located in northwest Russia. 
Fig. 3. Scatter plot of the proportion of forest $\left(\mathrm{P}_{\mathrm{f}}\right)$ vs. anthropogenic fragmentation $\left(\mathrm{P}_{\mathrm{fa}}\right)$ for each combination of continent and biome. The horizontal lines drawn at $\mathrm{P}_{\mathrm{f}}=40$ and 60 represent possible thresholds of connectivity (see text). For a given value of $\mathrm{P}_{\mathrm{f}}$, the relative value of $\mathrm{P}_{\mathrm{fa}}$ may help identify biomes and continents where anthropogenic fragmentation is more or less of an issue.

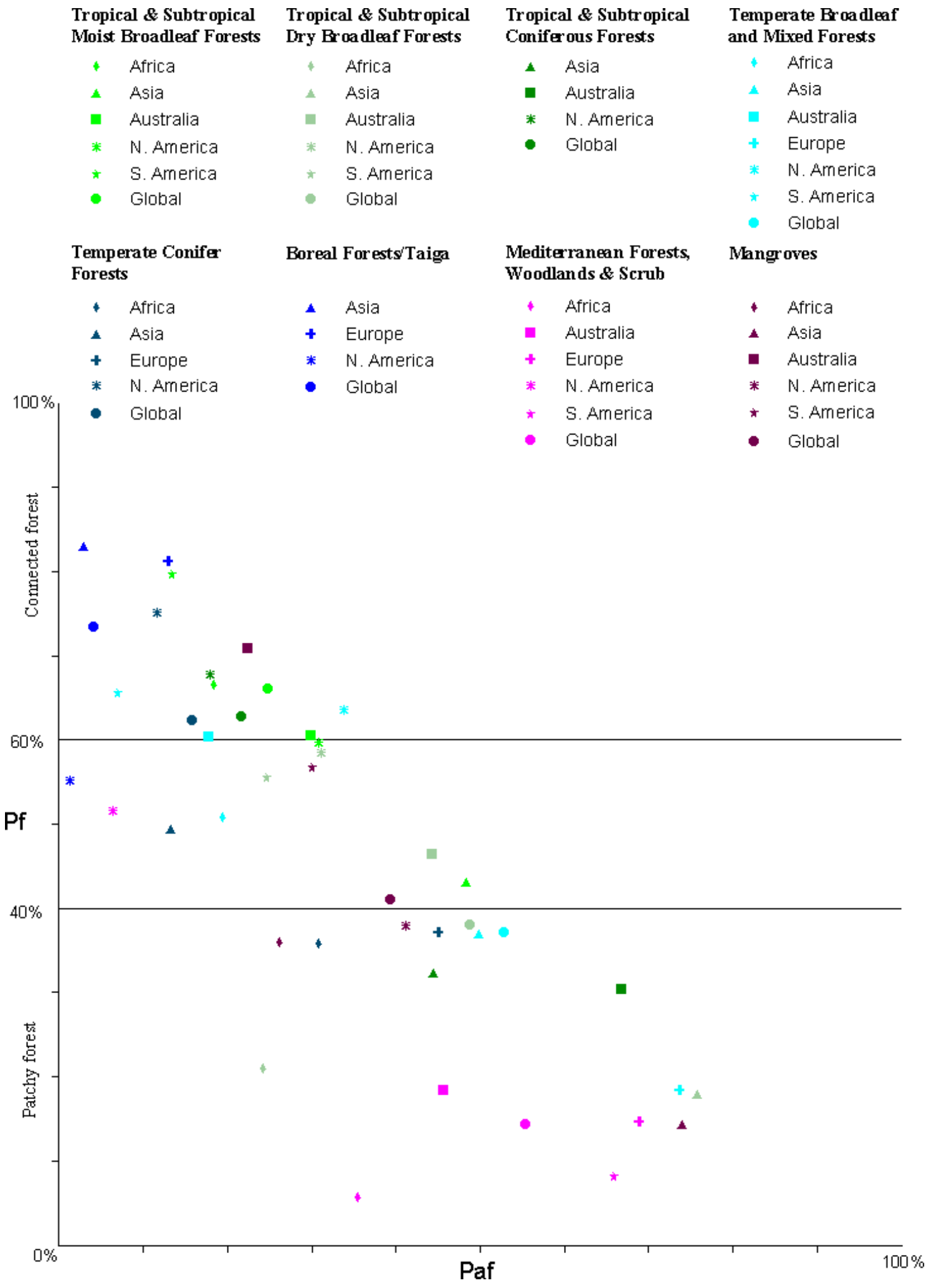


Table 6. Average percent $\mathrm{P}_{\mathrm{fa}}$ and $\mathrm{P}_{\mathrm{fn}}$ by WWF ecoregion for the tropical and subtropical moist broadleaf forest biome in South America. Higher values indicate more fragmentation.

Ecoregion

Araucaria moist forests

Atlantic Coast restingas

Bahia coastal forests

Bahia interior forests

Bolivian Yungas

Caatinga Enclaves moist forests

Caqueta moist forests

Catatumbo moist forests

Cauca Valley montane forests

Chocó-Darién moist forests

Cordillera La Costa montane forests

Cordillera Oriental montane forests

Eastern Cordillera real montane forests

Eastern Panamanian montane forests

Guayanan Highlands moist forests

Guianan moist forests

Gurupa varzeá

Iquitos varzeá

Japurá-Solimoes-Negro moist forests

Juruá-Purus moist forests

Madeira-Tapajós moist forests

Magdalena Valley montane forests

Magdalena-Urabá moist forests

Marajó Varzeá forests

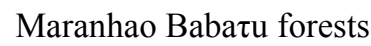

Mato Grosso seasonal forests

Monte Alegre varzeá

Napo moist forests

Negro-Branco moist forests

Northeastern Brazil restingas

Northwestern Andean montane forests

Orinoco Delta swamp forests

Guianan Freshwater swamp forests

Alta Paraná Atlantic forests

Pernambuco coastal forests
$\mathrm{P}_{\mathrm{fa}} \quad \mathrm{P}_{\mathrm{fn}}$

34.09

30.08

40.87

27.60

44.75

28.16

37.58

27.44

12.40

16.75

60.74

33.00

4.95

9.70

25.40

27.85

40.08

23.88

31.01

24.52

16.76

20.27

20.36

21.71

37.06

28.99

33.32

22.81

3.53

9.76

5.49

12.73

12.07

15.74

4.63

9.38

3.33

7.37

2.42

5.42

4.79

11.02

31.85

26.99

42.70

37.54

14.20

15.09

41.16

35.78

8.49

18.00

8.10

12.41

5.18

10.56

3.76

8.83

71.63

24.48

36.37

29.24

16.17

19.52

21.44

19.79

44.02

35.50

85.57

18.38 
Pernambuco interior forests

Peruvian Yungas

Purus varzeá

Purus-Madeira moist forests

Rio Negro campinarana

Santa Marta montane forests

Serra do Mar coastal forests

Solimoes-Japurá moist forest

Southern Andean Yungas

Southwest Amazon moist forests

Tapajós-Xingu moist forests

Tepuis

Tocantins/Pindare moist forests

Trinidad and Tobago moist forests

Uatuma-Trombetas moist forests

Ucayali moist forests

Venezuelan Andes montane forests

Western Ecuador moist forests

Xingu-Tocantins-Araguaia moist forests
86.75

19.60

22.10

23.23

3.43

6.62

3.82

7.87

6.47

11.82

44.00

30.59

38.40

29.25

2.84

5.69

17.58

24.99

2.02

6.57

2.54

13.67

6.13

25.47

17.55

21.28

25.68

3.75

22.84

6.76

8.55

20.30

13.04

49.59

21.62

(6.59

27.87

6.42

11.42

\section{DISCUSSION}

Summaries of forest connectivity by biome and continent were useful as an indicator of general condition. Comparing biome values across continents provided insight into global variation. Almost $50 \%$ of South American TrMB was interior forest, compared with only $16 \%$ in Asia. These summaries did not provide information on causes of low connectivity (high fragmentation).

Similar to connectivity summaries, summarizing $\mathrm{P}_{\mathrm{fa}}$ and $\mathrm{P}_{\mathrm{fn}}$ using biomes was useful as a broad indicator of forest fragmentation. Information about relative condition was again available by comparing across continents, but causes behind the fragmentation can now be quantified. The value of separating $\mathrm{P}_{\mathrm{fa}}$ from overall fragmentation for targeting purposes was evident in naturally patchy forest biomes. Total fragmentation in the boreal forest of North America was almost 23\%, but practically all was due to natural fragmentation. Because of the low level of human-caused fragmentation, protection or remediation measures are not likely to be necessary.

Biomes, however, were too large for summaries of $\mathrm{P}_{\mathrm{fa}}$ and $\mathrm{P}_{\mathrm{fn}}$ to be effective targeting tools for specific at-risk areas. For example, the TrMB biome in South America covered nearly half the continent, and the low overall $\mathrm{P}_{\mathrm{fa}}$ masked local problem areas, such as Rondonia where widespread deforestation has occurred. Smaller reporting units can provide more useful targeting information. Summaries using $54 \mathrm{WWF}$ ecoregions in the TrMB biome in South America reveal that all 27 ecoregions with $\mathrm{P}_{\text {fa }}$ over $20 \%$ were coastal or near-coastal. However, the Madeira-Tapajós moist forests ecoregion, which contains the Rondonia area, still had a low $\mathrm{P}_{\mathrm{fa}}$ of 4.79. The optimal way of targeting specific areas is to use $\mathrm{P}_{\mathrm{fa}}$ values at the pixel level.

Composite maps (Fig. 4A-F) are a useful way to identify local hot spots, by using actual $\mathrm{P}_{\text {fa }}, \mathrm{P}_{\text {fn }}$, and $\mathrm{P}_{\mathrm{ff}}$ pixel values instead of averages for a summary area. In South America, development in the Rondonia region was clearly visible in the Amazon basin as a large area of red and yellow patches (Fig. 4). Globally, areas displayed in yellow represented transition zones between connected forest and human-fragmented forest. With continued, contagious human land-use expansion, these areas will be the most likely to experience further degradation. In time, the transition zones may become highly fragmented and new transitional areas will appear deeper in the intact forest. Consequently, the yellow areas on the composite 
maps may represent excellent opportunities for protection or restoration. Protecting transitional and adjacent areas may limit further expansion or degradation of the transitional areas. Restoration efforts to eliminate or reduce fragmentation may produce larger patches of connected or interior forest. This is particularly true in the
TrMB biome in South America, currently the least fragmented of the major forests. There are numerous small patches of transitional areas that, if allowed to expand, could result in significant forest fragmentation and removal.

Fig. 4. Color composite showing the components of fragmentation. Pixels are individually rendered according to their measured values for $\mathrm{P}_{\mathrm{ff}}, \mathrm{P}_{\mathrm{fa}}$, and $\mathrm{P}_{\mathrm{fn}}$ (see text for explanation). Black represents continuous areas of non-forest natural land cover, and white areas were not included in the study.

To view a larger version of this figure, go to http://www.consecol.org/vol7/iss2/art7/figure4.html.

A.

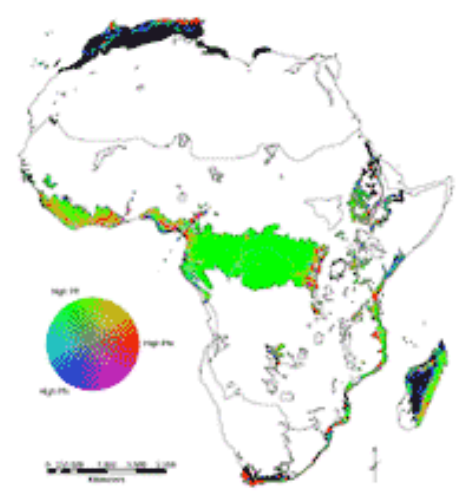

D.

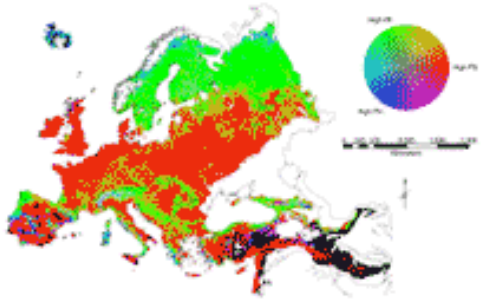

B.

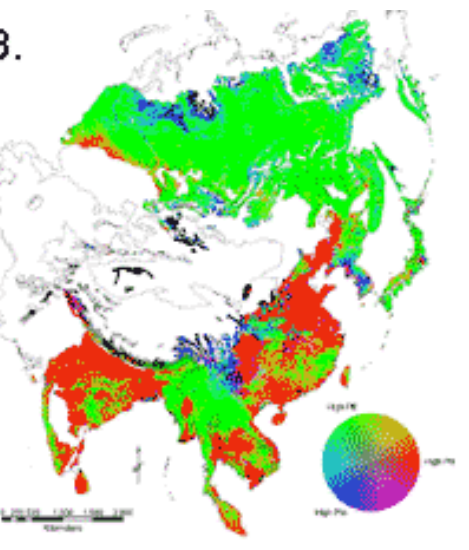

E.

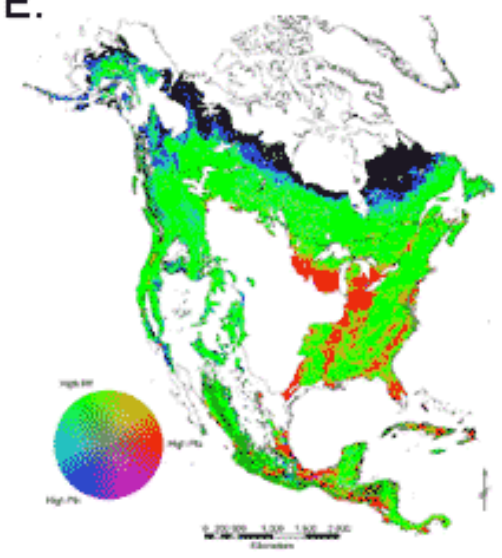

C.

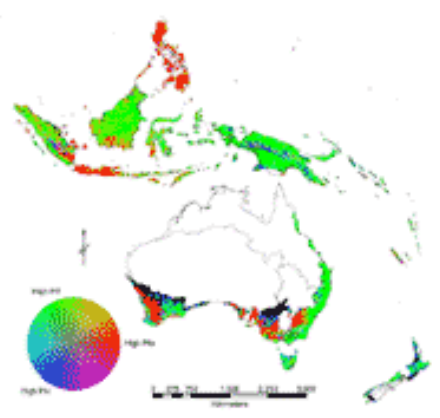

F.

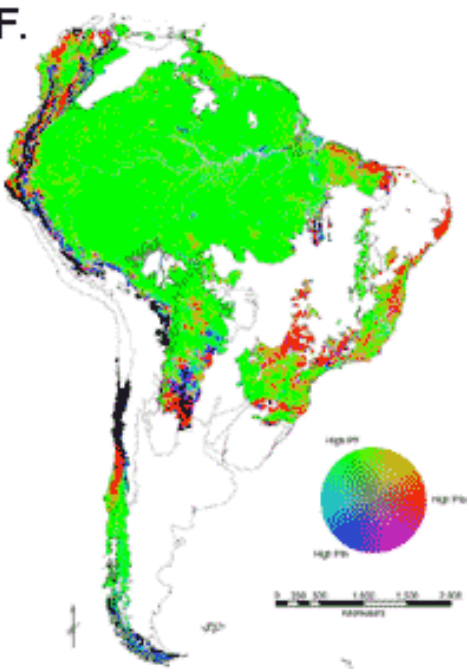


Fig. 5. The locations of extreme values of the $\mathrm{P}_{\mathrm{fa}}$ statistic.

To view a larger version of this figure, go to http://www.consecol.org/vol7/iss2/art7/figure5.html.

A.

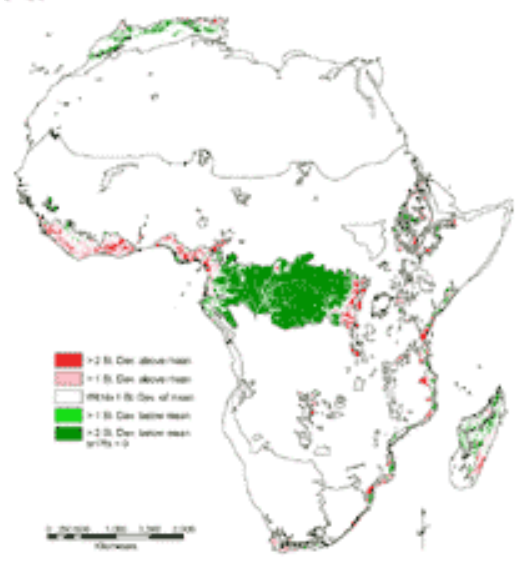

D.

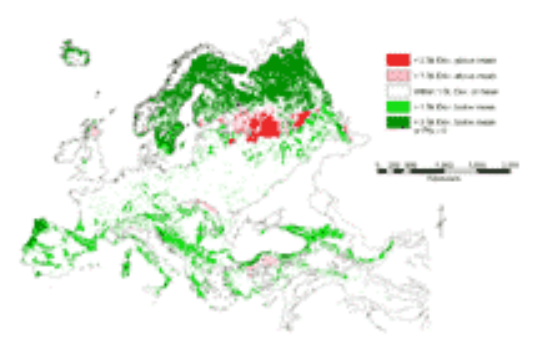

B.

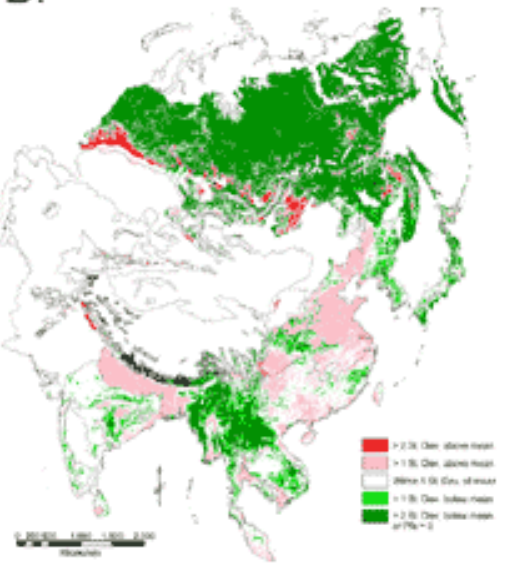

E.

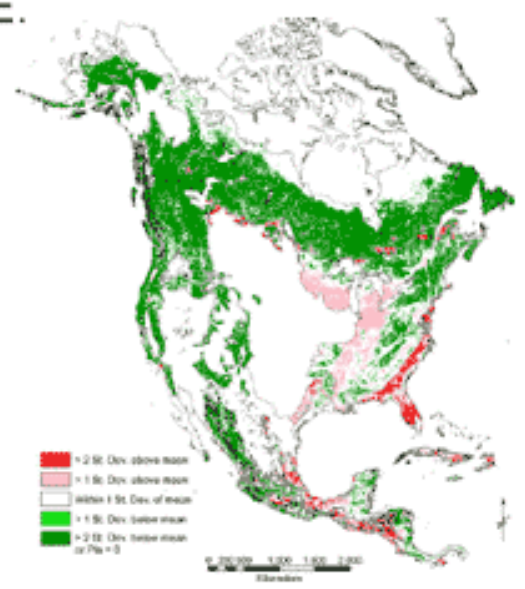

C.

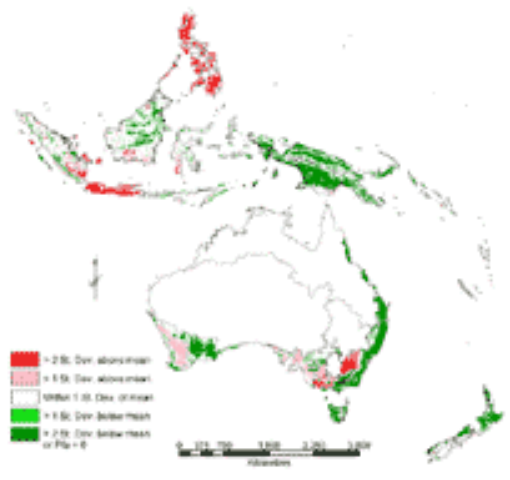

F.

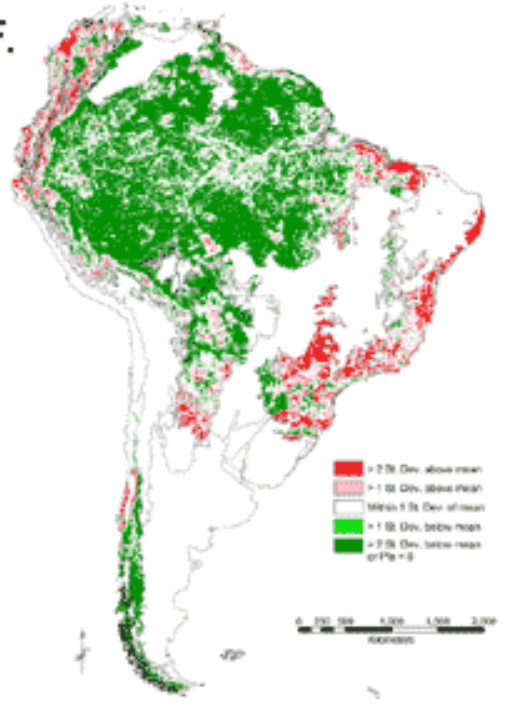

Standard deviation maps (Fig. 5A-F) are similar to composite maps in that they are useful for identifying specific areas of concern. Mapping relative humancaused fragmentation may be more useful for policy makers than composite maps. In Europe, for example, where temperate forests have largely been removed, the standard deviation map identified small patches with less or even no fragmentation. These areas could be prioritized for protection. Conversely, in South
America, where the TrMB biome was mostly intact, areas with average or higher amounts of fragmentation might be good candidates for restoration.

One goal of decision makers might be to maximize forest connectivity (Wickham et al. 1999). Critical values of $\mathrm{P}_{\mathrm{f}}$ are 40 and $60 \%$ according to percolation theory (Stauffer 1985). Figure 3 could be used as a general targeting tool to locate biomes near critical 
levels. Where $\mathrm{P}_{\mathrm{f}}$ is at or above $60 \%$, protective measures might be taken. Where $\mathrm{P}_{\mathrm{f}}$ is between 40 and $60 \%$, restoration might be undertaken, using composite maps, standard deviation maps, or some other tool to identify specific areas where actions would have the greatest impact. In addition, biomes with smaller amounts of forest are likely at higher risk than biomes with larger amounts of forest given equal $\mathrm{P}_{\mathrm{fa}}$ values. Figure 3 could help identify these areas. As an example, the $\mathrm{P}_{\mathrm{fa}}$ values were fairly low in the temperate conifer forest biome for both Asia (13.3\%) and North America (11.6\%). However, the $\mathrm{P}_{\mathrm{f}}$ value was much higher in North America (75-49\%), which places Asian temperate conifer forests at higher risk.

At $1-\mathrm{km}$ resolution, the GLCC data represents generalized land cover. Consequently, only very large urban areas are identified and the majority of anthropogenic-caused fragmentation at this scale was due to agriculture. The smoothing effect of coarseresolution data overemphasized the dominant land cover. In forested areas, it produced a "best case" fragmentation picture. Roads, a very important fragmenting agent (Riitters and Wickham 2003), and small perforations in the forest were not detected, creating a much more connected map than exists in reality. In human-dominated landscapes, forest may be portrayed as completely absent, when, in fact, small forest patches may exist.

The GLCC data is now over 10 years old, so recent development is not represented in our analyses. One example of underestimating fragmentation due to spatial and temporal limitations of the land cover was in the Amazonia region of South America. Although large areas of contiguous forest still exist, government policies have encouraged development in recent decades, including the construction of major highways (Laurance 2000). More recent, higher resolution land cover would better detect major roads and new urban and agricultural development, drastically increasing anthropogenic fragmentation scores in parts of the region.

A recent global land cover database derived from the MODIS sensor on the Terra satellite is currently under development (Friedl et al. 2002). An initial dataset is available, but substantial differences between the MODIS and GLCC precluded comparisons in this study. The MODIS land cover is expected to be updated quarterly, and should be valuable for identifying fragmentation trends in the future.

Non-forest biomes were not included in this study. The assumption that windows containing no forest, with an anthropogenic land use in the center pixel, were deforested would have been incorrect in these biomes. Clearly, forests in these regions could be important. A simple modification to the model could alter the assumption to ignore those pixels instead of classifying them as deforested. In this case, the assumption would be that windows with no forest never contained forest and would be displayed in white on a composite map regardless of center pixel land cover.

Forest fragmentation disregards threats to other important natural land cover types, such as wetlands, grasslands, and shrublands. The method presented in this paper can be easily extended to calculate fragmentation of any land cover type. The method presented is scale independent. Raster land cover data of any resolution may be used. Different window sizes may also be used, and may produce significantly different results (see Riitters et al. 1997, 2002). As such, it is important that decision makers apply the model at a scale appropriate to the policy under development. Reporting units of any size may be used to summarize fragmentation, which allows for multiscale assessments. For example, National Land Cover Data (NLCD; Vogelmann et al. 2001) could be used to examine fragmentation in the United States at $30-\mathrm{m}$ resolution, using one or more window sizes. Summaries could be provided at the state, county, and watershed level, along with color composite and standard deviation maps.

Intuitively, forest fragmented by anthropogenic sources is at higher risk of further fragmentation or removal than forest fragmented by natural causes. Identifying only human-caused forest fragmentation may be a useful tool for policy and decision makers, allowing for improved risk assessments and better targeting of areas for protection or remediation. The method presented produces data that may be summarized and displayed in a myriad of ways, each of which may be useful to the decision process.

Responses to this article can be read online at: http://www.consecol.org/vol7/iss2/art7/responses/index.html

\section{Acknowledgments:}

The United States Environmental Protection Agency (EPA), through its Office of Research and Development (ORD), partially funded and collaborated in the research described here under Interagency Agreement DW12939283-01-0 with 
the United States Department of Agriculture. It has been subjected to Agency review and approved for publication.

\section{LITERATURE CITED}

Bryant, D., D. Nielson, and L. Tangley. 1997. The Last Frontier Forests: Ecosystems and Economies on the Edge. World Resources Institute, Washington, D. C., USA.

Carvalho, K. S., and H. L. Vasconcelos. 1999. Forest fragmentation in central Amazonia and its effects on litterdwelling ants. Biological Conservation 91: 151-157.

Fearnside, P. M. 1996. Amazonian deforestation and global warming: carbon stocks in vegetation replacing Brazil's Amazon forest. Forest Ecology and Management 80: 2134.

Friedl, M. A., D. K. McIver, J. C. F. Hodges, X. Y. Zhang, D. Muchoney, A. H. Strahler, C. E. Woodcock, S. Gopal, A. Schneider, A. Cooper, A. Baccini, F. Gao, and C. Schaaf. 2002. Global land cover mapping from MODIS: algorithms and early results. Remote Sensing of Environment 83: 288-303.

Gardner, R. H., B. T. Milne, M. G. Turner, and R. V. O'Neill. 1987. Neutral models for the analysis of broadscale landscape pattern. Landscape Ecology 1: 19-28.

Gascon, C., and T. E. Lovejoy. 1998. Ecological impacts of forest fragmentation in central Amazonia. Zoology 101: 273-280.

Hargis, C. D., J. A. Bissonette, and D. L. Turner. 1999. The influence of forest fragmentation and landscape pattern on American martens. The Journal of Applied Ecology 36: 157-172.

Holmgren, P. 2001. Forest area and area change. Pages 115 in A. Perlis, editor. Global forest resources assessment 2000; Main report. FAO Forestry Paper 140; FAO, Rome, Italy.

Jones, K. B., T. G. Wade, J. D. Wickham, K. H. Riitters, and C. M. Edmonds. 1999. Characterizing Forest Fragmentation and Vulnerability Based on Patch Characteristics. USDA Forest Service Proceedings RMRS$\mathrm{P}-12$.

Jules, E. S., E. J. Frost, L. S. Mills, and D. A. Tallmon. 1999. Ecological consequences of forest fragmentation in the Klamath region. Natural Areas Journal 19: 368-378.

Justice, C., D. Wilkie, Q. Zhang, J. Brunner, and C. Donoghue. 2001. Central African forests, carbon and climate change. Climate Research 17: 229-246.

Kurki, S., A. Nikula, P. Helle, and H. Linden. 2000. Landscape fragmentation and forest composition effects on grouse breeding success in boreal forests. Ecology 81:19851997.

Laurance, W. F. 2000. Mega-development trends in the Amazon: implications for global change. Environmental Monitoring and Assessment 61: 113-122.

Laurance, W. F., H. L. Vasconcelos, and T. E. Lovejoy. 2000. Forest loss and fragmentation in the Amazon: implications for wildlife conservation. Oryx 34: 39-45.

Loveland, T. R., and A. S. Belward. 1997. The IGBP-DIS global $1 \mathrm{~km}$ land cover data set, Discover first results. International Journal of Remote Sensing 18: 3289-3295.

Loveland, T. R., B. C. Reed, J. F. Brown, D. O. Ohlen, Z. Zhu, L. Yang, and J. W. Merchant. 2000. Development of a global land cover characteristics database and IGBP DISCover from 1-km AVHRR data. International Journal of Remote Sensing 21: 1303-1330.

Matthews, E. 2001. Forest Briefing No. 1; Understanding the FRA 2000. World Resources Institute, Washington, D. C., USA.

Matthews, E., R. Payne, M. Rohweder, and S. Murray. 2000. Pilot Analysis of Global Ecosystems (PAGE): Forest Ecosystems. World Resources Institute, Washington, D. C., USA.

Milne, B. T. 1992. Spatial aggregation and neutral models in fractal landscapes. American Naturalist 139: 32-57.

Olson, D. M., E. Dinerstein, E. D. Wikramanayake, N. D. Burgess, G. V. N. Powell, E. C. Underwood, J. A. D’Amico, H. E. Strand, J. C. Morrison, C. J. Loucks, T. F. Allnutt, J. F. Lamoreux, T. H. Ricketts, I. Itoua, W. W. Wettengel, Y. Kura, P. Hedao, and K. Kassem. 2001. Terrestrial ecoregions of the world: a new map of life on Earth. BioScience 51: 933-938.

Pahari, K., and S. Murai. 1999. Modelling for prediction of global deforestation based on the growth of human population. Journal of Photogrammetry and Remote Sensing 54: 317-324.

Riitters, K. H., R. V. O'Neill, and K. B. Jones. 1997. Assessing habitat suitability at multiple scales: a landscapelevel approach. Biological Conservation 81: 191-202.

Riitters, K. H., and J. D. Wickham. 2003. How far to the nearest road? Frontiers in Ecology and the Environment 1: 125-129.

Riitters, K., J. Wickham, R. O'Neill, B. Jones, and E. Smith. 2000. Global-scale patterns of forest fragmentation. Conservation Ecology 4: 3. [Online] URL: http://www.consecol.org/vol4/iss2/art3.

Riitters, K. H., J. D. Wickham, R. V. O'Neill, K. B. Jones, E. R. Smith, J. W. Coulston, T. G. Wade, and J. H. Smith. 2002. Fragmentation of continental United States 
forests. Ecosystems 5: 815-822.

Scariot, A. 1999. Forest fragmentation effects on palm diversity in central Amazonia. The Journal of Ecology 87: 66-76.

Semazzi, F. H. M., and S. Yi. 2001. A GCM study of climate change induced by deforestation in Africa. Climate Research 17: 169-182.

Stauffer, D. 1985. Introduction to Percolation Theory. Taylor and Francis, Philadelphia, Pennsylvania, USA.

Virgos, E. 2001. Role of isolation and habitat quality in shaping species abundance: a test with badgers (Meles meles L.) in a gradient of forest fragmentation. Journal of Biogeography 28: 381-389.

Vogelmann, J. E., S. M. Howard, L. Yang, C. R. Larson, B. K. Wylie, and N. van Driel. 2001. Completion of the 1990s National land cover data set for the conterminous United States from Landsat Thematic Mapper data and ancillary data sources. Photogrammetric Engineering and Remote Sensing 67: 650-662.

Wickham, J. D., K. B. Jones, K. H. Riitters, T. G. Wade, and R. V. O'Neill. 1999. Transitions in forest fragmentation: implications for restoration opportunities at regional scales. Landscape Ecology 14: 137-145.

Zhang, H., A. Henderson-Sellers, and K. McGuffie. 2001. The compounding effects of tropical deforestation and greenhouse warming on climate. Climatic Change 49: 309338. 